\title{
Research of the technical characteristics of the electromechanical drive system of spiral classifier
}

\author{
V. Dmitriev \\ https://doi.org/10.31174/NT2018-158VI18-12 \\ State Higher Educational Institution "National Mining University“, Dnipro, Ukraine \\ Corresponding author. E-mail: vallerii.dmitriev@gmail.com
}

Paper received 13.02.18; Accepted for publication 19.02.18.

\begin{abstract}
Annotation. The sources of forced oscillations of the electromechanical system of the spiral classifier under the action of the disturbing moment from the portion of sand between the lugs are considered. Spectral analysis of the power signal consumed by the spiral drive is performed and the estimation of the possibility of using the amplitude-frequency characteristics of the oscillations for the tasks of automatic monitoring of technical and technological parameters is given.
\end{abstract}

Keywords: spiral classifier, electromechanical system, spectral decomposition of the signal, automatic control.

Introduction. Spiral classifiers are one of the most common aggregates in the technology of iron ore enrichment. They are usually installed in the first stage of ore preparation of the ore processing line, operate in a cycle with drum mills $[1,3]$ and perform a hydraulic classification of the ore crushed in the mill with separation into "finished" and "unmilled" grades. The latter is deposited in the classifier bath and is released in the form of "sands", which are returned to the mill's drum by means of a spiral.

The classifier spiral is a complex aggregate and includes a large number of elements, whose technical characteristics determine the operability of the entire electromechanical system [2] of the classifier.

Status of the question. Automation of control and management processes determines the search and justification of control methods, based on the technical and technological characteristics of the units. In the case of the spiral classifier, in the known automatic control and regulation systems [1, 3], grinding and classification processes do not include special sensors for automatic monitoring of the technical condition of the spiral and automatic control of productivity over the sands. Evaluation of the latter by indirect parameters, for example, according to the average value of the active current or power [3], consumed by the driving motor of the spirals, leads to a significant error $(30 . . .50) \%$ and drift of the characteristics of control in time.

Aim of the reseach. To evaluate the possibility of automatic control of the technical condition of the spiral and the technological parameter of productivity in the sands by the amplitude-frequency characteristics of the power signal of the driving motor of the spiral under the action of a disturbing moment, during the movement and dropping of a portion of sands.

The methods of experimental studies, spectral decomposition, amplitude-frequency analysis of power signals of the driving motor of the classifier spiral, methods of statistical analysis have been used in the work.

The results of the research are that oscillations of the active drive power signal characterize the oscillations of the mechanical elements of the spiral, which are caused by the action of the disturbing moment during the movement and dropping of portions of sands.

Scientific novelty of the research is that for the first time the possibility of constructing an automatic performance control over the sands with the use of the technical characteristics of the spiral and with the signal of the active drive power of the electromechanical system is justified.

Practical significance is that the amplitude-frequency characteristic of the oscillations can be used to evaluate the technical characteristics of the spiral state and the technological estimation of the mass of sand portions for the construction of automatic control means.

Main part. A simplified electromechanical system of the double-spiral classifier is shown in Figure 1. Shafts with spirals 1, gears of open 2 and closed 4 types, rigid 3 and elastic 5 couplings of connection of intermediate shafts and a shaft of the driving electric motor 6 are represented here.

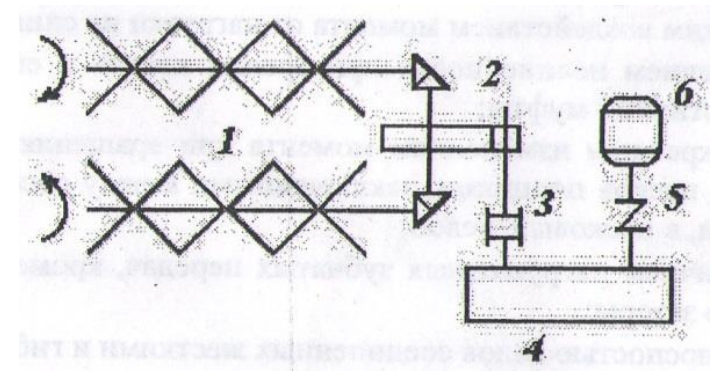

Figure 1. Simplified electromechanical system of the doublespiral classifier with the electric drive

On the assumption of normal process of classification in the classifier bath, i.e. under a pulp consistency (1200...1700) grams per liter, building-up process of sands is even in classification and the sand batches are afforded of truncated cone form between the spiral blades. The spiral blades move the sand batches directly and periodically load spokes those retain them (a single spiral turn retains 6 spokes on the shaft). This spokes loading leads to the periodical loading along the spiral shaft. It happens because of the spokes fixed on the shaft during the running of the rotary shaft that moves sand batches.

A motional energy transfer from the rotary shaft of the driving motor runs further along the chain (Figure 1): the flexible coupling 5 , the close reducing gear 4 , the ridig coupling 3 , the close gear drive 2 , the shafts 1 of the spiral classifier, the spiral blades, the movable sand batches. This energy transfer scheme let us to make an assumption of possibility of the movable sand mass estimation and the evaluation of sand batches dumped into the sand chute through the active power consumption with the conducted electric motor 6. Also we need to give an estimate of possibility of the power signal splitting to be disaggregated into the permanent and the dynamic power, evaluate their contribution to the general signal.

A constant component defines the typical expenditures for sand batches movement, friction between sands, between 
sands and blade, bearing and gear face friction, coupling and electric motor coil energy loss. The consequence of this is the change in the average values of power in time with a change in the energy losses due to friction, losses in clutches and windings, which depend on the size of the sands, technological regimes, operating conditions of the equipment, etc.

The dynamic components may contain information on sands batches mass transported and dumped to the sand coupling. The example for the electromechanical breaker systems is provided in [5].

All the main sources of excitation of the oscillations of the spiral classifier as an electromechanical system, leading to oscillations in the signal of the driving motor power, have their characteristic frequency of oscillations and corresponding amplitude, which to some extent depends on the total load of the transported sands, has different energy intensities and contribution to the total signal of the active power consumed.

It is natural that a source that is less liable to the impact of both the frequency and amplitude interferences are of the strongest interest to the sands load control problems.

We consider the main sources of the mentioned ones and analyze their frequencies and amplitudes based on the technical parameters of the classifier 2КПC-2,4.

1. The oscillations evoked by spiral shafts unbalance and discrete expansion of some elements significantly depend on the mechanical engineering assemblies and elements condition. For example, the blade or fettling breakage and the spoke rupture result in oscillation amplitude growth with the same values of the sand load. The frequency of these oscillations equal to the rotation frequency of the spiral shaft:

$$
f_{1}=\frac{n}{60} \mathrm{~Hz},(1)
$$

where $n$ is the rotating velocity of the spiral shaft, rpm, at $n=1,69 \mathrm{rpm}, f_{1}=0,033 \mathrm{~Hz}$.

2. A periodical load of spokes those hold the spiral blades at their successive load into the sands results in the applicable change of the driving torque, i.e. also results in oscillations with the frequency proportional to the spoke number for one spiral coil. Classifiers under consideration usually have 6 spokes each of them is $60^{\circ}$ out of spiral coil circle. The oscillation frequency is determined as:

$$
f_{2}=6 \cdot f_{1}=6 \cdot \frac{n}{60} \mathrm{~Hz},(2)
$$

and at $n=1,96 \mathrm{rpm} f_{2}=6 \cdot 1,96 / 60=0,1956 \approx 0,2 \mathrm{~Hz}$.

3. Gear drives lead to the oscillations with frequencies:

$$
f_{3}=Z_{i} \cdot f_{1} \mathrm{~Hz},(3)
$$

where $Z_{i}$ - a number of a gearwheel teeth.

These are the so-called "tooth frequencies". Their amplitude is characterized by the transferred torque moment (by load) by the teeth wear rate and gaps at the gear drive mounting. For example, teeth frequencies during the contact interaction of teeth of the exposed drive 2 conical pair (see Figure 1):

$$
f_{3}=76 \cdot 1,96 / 60=2,417 \approx 2,4 \mathrm{~Hz} .
$$

4. The elastic clutch brings to the nonlinear torque moment conversion. It causes the torsional vibrations at the system divided by this clutch into the shaft and reducer on the one part and rotor of the driving motor.

Imagine electromechanical classifier as bimass system
(Figure 1), where $J_{1}$ - a point moment of spiral classifier and reducer inertia, $J_{2}-$ a point moment of motor spindle inertia, $g_{1,2}-$ a rigidity of the elastic clutch. A differential motion equation system of this system may be represented as [8]:

$$
\left\{\begin{array}{l}
J_{1} \cdot \ddot{\varphi}_{1}+C_{1,2}\left(\varphi_{1}-\varphi_{2}\right) \\
J_{2} \cdot \ddot{\varphi}_{2}-C_{1,2}\left(\varphi_{1}-\varphi_{2}\right)
\end{array},\right.
$$

where $\varphi_{1}, \varphi_{2}$ - the instantaneous angles of mass rotation relative to the certain initial position.

In order to find a partial solution of this system we need to make such evaluations:

$$
\left\{\begin{array}{l}
\varphi_{1}=A_{1} \cdot \sin \left(\omega_{c} \cdot t+E\right) \\
\varphi_{2}=A_{2} \cdot \sin \left(\omega_{c} \cdot t+E\right)
\end{array} .(5)\right.
$$

Let's substitute values (5) at the system (4). When we solve it relatively to the natural frequency $\omega_{c}$ of the system we get $[8,9]$ :

$$
\omega_{c}=\sqrt{\frac{C_{1,2}\left(J_{1}+J_{2}\right)}{J_{1} \cdot J_{2}}} .
$$

From the expression (6) appears that frequency $\omega_{c}$ is characterized by the common condition of electromechanical system and is proportional to the coupling rigidity. The sands load forms a part of $J_{1}$ as the adjoint inertia moment and more over has a damping effect on the oscillations amplitude. As it is seen from the above the utilization of the system natural frequency for sands load evaluation is difficult enough. According to the available information $\omega_{c}$ for the submerged $(\mathrm{KCH})$ and unsubmerged (КСП) types of classifier is varying from 5 to $10 \mathrm{~Hz}$.

The elastic clutch is located directly in front of the driving motor and functions as low-pass filter [8], i.e. oscillations with higher frequencies than cutoff frequencies $f_{c f}$ of the clutch do not go through and we do not find them reasonable to analyze. The analysis shows that for clutches used under the conditions of enterprises namely for 5 petal clutches and ones made of transport rubber $f_{c f} \geq 5 \mathrm{~Hz}$.

5. The feature of spiral classifier design has two overhangs. It dumps the sand batches into the sand chute in a single revolution. This results in torque moment oscillation and power consumption of the electric motor accordingly. The frequency of these oscillations is determined as:

$$
f_{4}=2 \cdot f_{1} \mathrm{~Hz},(7)
$$

$$
\text { and at } n=1,96 \mathrm{rpm} f_{4}=2 \cdot 1,96 / 60=0,06536 \approx 0,065
$$
$\mathrm{Hz}$.

The spiral of classifier and its determined elements are directly influenced by sands load. That is why the dynamics of spiral has certain advantages for checking the problem. Besides the frequencies $f_{1}, f_{2}, f_{4}$ the spiral also generates other frequencies of forced oscillations by the action of the external load with the variable component. Identification of the spiral dynamic behaviors [2] occurs by the way of the dynamic equivalent shaft with the torsional rigidity that changes periodically with the frequency $6 \omega$ (since spiral has 6 spokes at section which successively take the effect of the moment from the sands load). The solution of the differ- 
ential equation of this shaft motion [9] has shown a wide frequency range of the forced oscillations presented in Figure 2. Here is represented: a dashed line corresponds to the main frequency of the classifier spiral (shaft) rotation; the thick long lines correspond to the frequencies $2 \omega$ and $6 \omega$ under relevant oscillations of the external moment and rigidity; the thick short lines characterize shaft oscillation with frequencies $4 \omega$ and $8 \omega$; the thin short lines correspond to the frequencies emerged in the forced oscillation of the shaft subject to the nonsymmetric changes of rigidity and external moment.

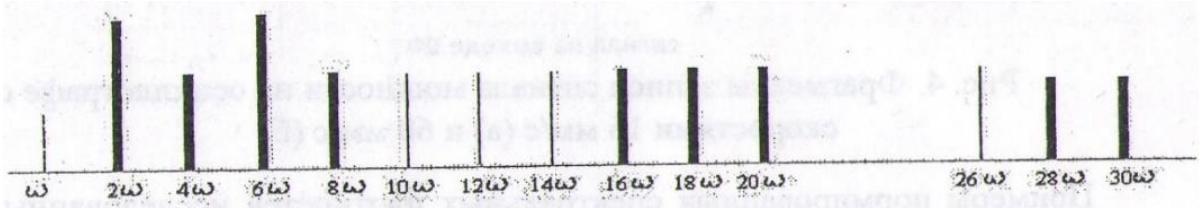

Figure 2. Frequency spectrum of the spiral shaft forced oscillation

6. Oscillations caused by the nonsymmetric location of motor spindle at the stator magnetic field characterize changes of the total load on the driving motor that also turns on the load on sands. The frequency of these oscillations is:

$$
f_{5}=\frac{\omega_{g}}{60} \mathrm{~Hz},(8)
$$

where $\omega_{g}$ - the rotor speed of the driving motor, rpm.

$$
f_{5}=485 / 60=8,083 \approx 8,1 \mathrm{~Hz} .
$$

The other types of the oscillation sources may in a less degree characterize the sands load. That is the reason why we do not consider them.

In some enterprises of the manufacturing environments such as _Mining and Metallurgical Company of Tyrnyauz, north ore-dressing and processing enterprise and mining and smelting complex of Navoiy experimental researches of power signal of spiral driving motor for different kinds of classifiers - 2КСП-24, 2КСН-246 1КСП-30 were done. The goal of researches was an experimental test of the control method and evaluation of the spectral component of the power signal under the various sands loads for revealing of the most informational frequencies (or frequency range).

In process of the researches the oscillography of the power signals for various load duties of spiral classifier were carried out. The load duties were determined with an impact on the feed ore and water consumption at the grinding cir- cuit. The assessment of the sands load were made by the average value of the active power consumed by the driving motor in the form of the ensemble average of the signal realization recording $-M(x)$ on the oscillograms.

In this paper the information capability of the power spectral components made under the Navoiy mining and smelting complex conditions was analyzed by the 2 КСП-2,4 classifier. The analogous results were made at the others enterprises.

To study the level of the dynamic component at each analyzed frequency, i.e. estimating the contribution of the power signal dispersion, a well-known spectral analysis method using Fourier transforms was used [6]. According to the practical recommendations given in [6], the normalized estimate of the spectral density is taken as the initial formula for calculating the estimate of the spectral density of signals.

Stationarity and ergodicity of the analyzable random processes must be provided in accordance with the recommendations made in [6].

In order to reduce errors of spectral density of the correlation function figured out according to the finite member function [6] a complementary function of the correlation window "Bartlett window" is introduced.

According to the abovementioned expressions (10-13) a special program for spectral density calculation "SPEKTR" for study of the power signal of spiral driving motor is written.

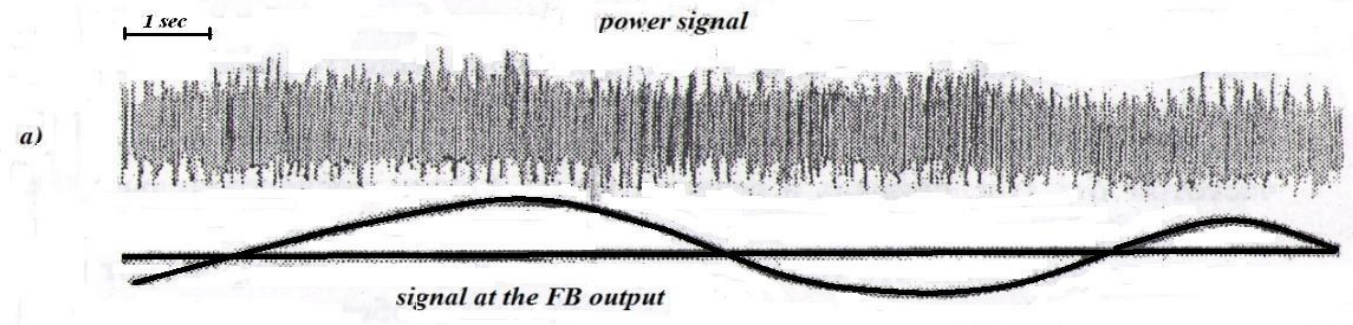

power signal

b)

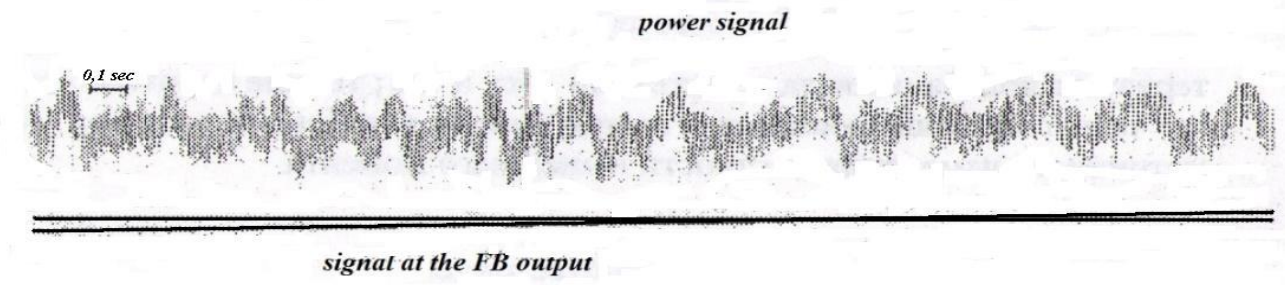

Figure 3. Capture sample of the power signal on the oscillogram at the $16 \mathrm{~mm} / \mathrm{s}$ (a) and $60 \mathrm{~mm} / \mathrm{s}$ (b) speeds

In order to improve the calculation accuracy and spectral density analysis the signal recording from the power con- verters was carried out at two speeds $-16 \mathrm{~mm} / \mathrm{s}$ and 60 $\mathrm{mm} / \mathrm{s}$. 
Thus, at the $1^{\text {st }}$ speed the analysis in the $0 \ldots 1 \mathrm{~Hz}$ range, at the $0,005 \mathrm{~Hz}$ interval was made, at the $2^{\text {nd }}$ speed in the $0 \ldots 10$ $\mathrm{Hz}$ range in the $0,1 \mathrm{~Hz}$ interval.

At the same time a signal with a filter cutoff frequency $f_{c f 1}=1,0 \mathrm{~Hz}$ and $f_{c f 2}=10 \mathrm{~Hz}$ is separated and recorded on the oscillograph by the low-pass filter (FB) to study the action of the very-low-frequency signals.

The capture sample of the power signal on the oscillogram at the $16 \mathrm{~mm} / \mathrm{s}$ speed is performed in Figure 3(a), the sample made at the $60 \mathrm{~mm} / \mathrm{s}$ speed - in Figure 3. A signal from the active power converter is represented at the top of the oscillogram, the output signal from the FB filter - at the bottom part.

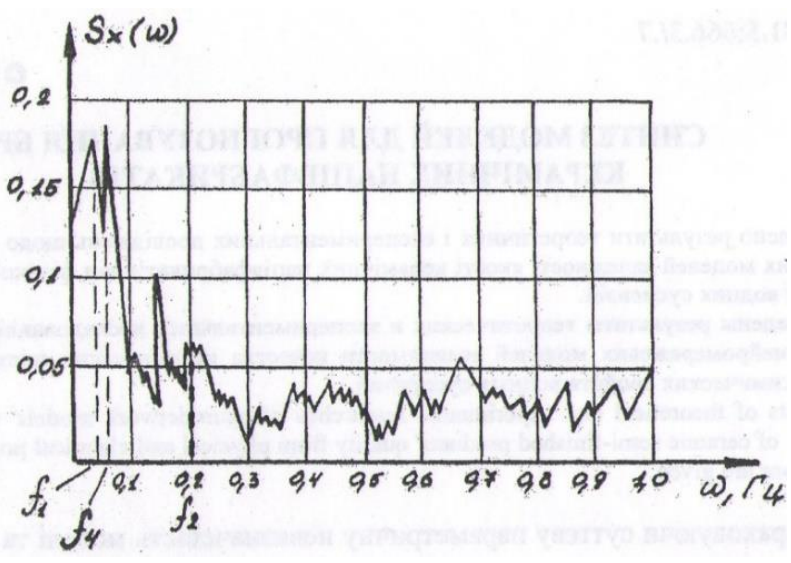

Figure 4. Graphic of normalized spectral density of power signal at the $16 \mathrm{~mm} / \mathrm{s}$ recording speed

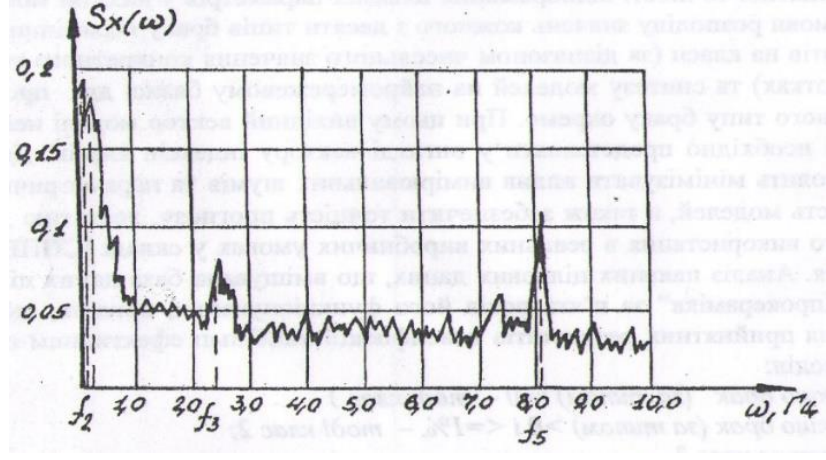

ü

Figure 5. Graphic of normalized spectral density of power signal at the $60 \mathrm{~mm} / \mathrm{s}$ recording speed

The examples of the normalized spectral density of the examined power signals are shown in Figure 4 and Figure 5.

The results of the calculation by the "SPEKTR" program and the analysis are presented in the table 1 - for oscillogram recorded at the $60 \mathrm{~mm} / \mathrm{s}$ speed and in the table 2 - for oscillogram recorded at the $16 \mathrm{~mm} / \mathrm{s}$ speed for $0-10 \mathrm{~Hz}$ and $0-1$ $\mathrm{Hz}$ ranges in various technological modes of the classifier. Thus, more than 60 oscillograms were processed for both recording speeds. The analogous results were obtained.

The analysis of the experimental results confirms the corollaries about amplitude variation at the all studied frequencies with sands load, i.e. they may work as the required data source. However, their contribution to the common energy level of the signal is different. Moreover, each of them depends on the technical conditions of the vibration source.

Table 1. The processing results of the oscilograms with $60 \mathrm{~mm} / \mathrm{s}$ speed, arbitrary unit

\begin{tabular}{|c|c|c|c|c|c|c|}
\hline \multirow[b]{2}{*}{ Name } & \multirow{2}{*}{$\begin{array}{c}\text { Assembly } \\
\text { average } \\
M(x)\end{array}$} & \multirow{2}{*}{$\begin{array}{c}\text { Mean square } \\
\text { deviation } \\
\sigma_{x}\end{array}$} & \multirow[b]{2}{*}{$\begin{array}{c}\text { Dispersion } \\
D(x)\end{array}$} & \multicolumn{3}{|c|}{ Value degree $S(x)$ on the frequency, $\mathrm{Hz}$} \\
\hline & & & & $\begin{array}{l}0,2 \\
f_{2}\end{array}$ & $\begin{array}{l}2,4 \\
f_{3}\end{array}$ & $\begin{array}{l}8,1 \\
f_{5}\end{array}$ \\
\hline Condition 1 & 66,26 & 5,718 & 32,7 & 0,885 & 0,349 & 0,471 \\
\hline Condition 2 & 61,40 & 5,211 & 27,155 & 0,721 & 0,264 & 0,311 \\
\hline Condition 3 & 50,44 & 4,301 & 18,489 & 0,596 & 0,167 & 0,196 \\
\hline Condition 4 & 43,37 & 3,607 & 13,01 & 0,261 & 0,111 & 0,135 \\
\hline
\end{tabular}

Table 2. The processing results of the oscilograms with $16 \mathrm{~mm} / \mathrm{s}$ speed, arbitrary unit

\begin{tabular}{|c|c|c|c|c|c|c|}
\hline \multirow[b]{2}{*}{ Name } & \multirow{2}{*}{$\begin{array}{c}\text { Assembly } \\
\text { average } \\
M(x)\end{array}$} & \multirow{2}{*}{$\begin{array}{c}\text { Mean square } \\
\text { deviation } \\
\sigma_{x}\end{array}$} & \multirow[b]{2}{*}{$\begin{array}{c}\text { Dispersion } \\
D(x)\end{array}$} & \multicolumn{3}{|c|}{ Value degree $S(x)$ on the frequency, $\mathrm{Hz}$} \\
\hline & & & & $\begin{array}{c}0,035 \\
f_{1}\end{array}$ & $\begin{array}{c}0,065 \\
f_{4}\end{array}$ & $\begin{array}{l}0,2 \\
f_{2}\end{array}$ \\
\hline Condition 1 & 66,26 & 5,718 & 32,7 & 0,911 & 0,998 & 0,395 \\
\hline Condition 2 & 61,40 & 5,211 & 27,155 & 0,811 & 0,865 & 0,318 \\
\hline Condition 3 & 50,44 & 4,301 & 18,489 & 0,595 & 0,625 & 0,279 \\
\hline Condition 4 & 43,37 & 3,607 & 13,01 & 0,248 & 0,391 & 0,165 \\
\hline
\end{tabular}

The research of signals and driving motor power at idling speed of spiral (when the spiral is raised) has not revealed the dominant frequencies. In this case the spiral spectral density is almost a flat spectrum with a continuous roll-off higher then $\approx 10 \mathrm{~Hz}$ frequency. It also affirms an induce character of frequencies on a specified frequencies under the sands load (of the external moment).

The results of the theoretical and experimental researches have affirmed the possibility of the informative frequency choice equal to the double reversible shaft of spiral $\left(f_{4}\right)$. This frequency is characterized by the sampling period of sands dumping into the sand chute as the most noise-resistant frequency with considerable duty.
The rotational frequency of the shaft rotation $f_{1}$ also has considerable duty. However, it is less noise-resistant because its amplitude depends on the shaft rigidity and its residual deformation, on the journal and thrust bearing condition, etc.

The frequencies $1 \omega$ and $6 \omega$ are located on either side of frequency $f_{4}$ (see Figure 4 ). They have considerable duty and may become the biggest part of the error receiving the information at the frequency $f_{4}$.

Asynchronous electric motors are used for the drive spiral classifier. Their soft mechanical feature results in the rotor speed and shaft mechanical moment [7] characteristics. This, in its turn, results in a certain change of shaft speed at the change of the classifier loading by the circulate sands. It is 
established that speed reduction from the idle speed to the torque rating is $10 \%$ for this electric motor. Therefore a shaft

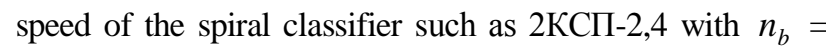
$1,96 \mathrm{rpm}$ may change within the range of $\pm 0,1 \mathrm{rpm}$ from the rated one and change of the informative frequency may be \pm $0,005 \mathrm{~Hz}$ from the center frequency $f_{4}=0,065 \mathrm{~Hz}$.

Conclusions. The results of the theoretical and experimental researches have shown the utilization possibilities of the amplitude frequency response of the spiral shaft and, respectively, the driving motor power signal for evaluation the sands mass as batches, which are transportable along the classifier bath and dumped into the sands clutch, and evaluations of the technical state of the elements of the electrome- chanical system.

The double rotational frequency $f_{4}$ is the most informative and noise-resistant among the considered frequencies. It characterizes the frequency of the sands batches dumping

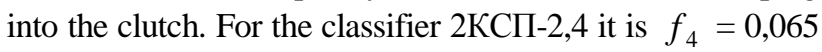
$\mathrm{Hz}$.

Consequently, the possibility of development of the checking facilities of the spiral classifier among sands according to the usage of the amplitude frequency response of the dynamic component of the spiral driving motor power signal has been confirmed, both as a separate automatic device and as a special software product.

\section{REFERENCES}

1. Хан, Г.А. Автоматизация обогатительных фабрик / Г.А. Хан, В.П. Картушин, Л.В. Сорокер, Д.А. Скрипчак. - М.: Недра, 1974. $-280 \mathrm{c}$.

2. Корсун, В.И. Идентификация динамических характеристик спирали классификатора и их практическая проверка / В.И. Корсун, А.Н. Марюта, В.И. Дмитриев // Автоматический контроль и управление в цветной металлургии. Тезисы докладов РНТС. - Ташкент, 1983. -28 с.

3. Тихонов, О.Н. Автоматизация производственных процессов на обогатительных фабриках / О.Н. Тихонов. - М.: Недра, 1985. $-272 \mathrm{c}$.

4. Улитенко, К.Я. Определение циркулирующей нагрузки измельчительных агрегатов в АСУ ТП / К.Я. Улитенко, Р.П

Маркин // Обогащение руд. - С-Пб., 2005. - №2 - С. 42-44.

5. Качан, Ю.Г. Модель формирования активной мощности приводного электродвигателя конусной дробилки / Ю.Г. Качан, В.И. Корниенко. - Изв. вузов. Горный журнал. - 1987. №3. - С. 109-113.

6. Бендат, Дж. Измерение и анализ случайных процессов / Дж. Бендат, А. Пирсол. - М.: Мир, 1974. - 650 с.

7. Пиотровский, Л.М. Электрические машины / Л.М. Пиотровский. - М. - Л.: Энергия, 1972. - 504 с.

8. Маслов, Г.С. Расчеты колебаний валов / Г.С. Маслов. - М.: Машиностроение, 1980. - $151 \mathrm{c}$.

9. Бизерман, В.Л. Теория механических колебаний / В.Л. Бизерман. - М.: Высшая школа, 1980. - 408 с.

\section{REFERENCES}

1. Khan, G.A. Automation of concentrating factories / G.A. Khan, V.P. Kartushin, L.V. Soroker, D.A. Skripchak. - Moscow: Nedra, 1974. -280 p.

2. Korsun, V.I. Identification of the dynamic characteristics of the classifier spiral and their practical verification / V.I. Korsun, A.N. Mariuta, V.I. Dmitriev // Automatic control and management in non-ferrous metallurgy. Abstracts of the RNTS. - Tashkent, 1983. $-28 \mathrm{p}$.

3. Tikhonov, O.N. Automation of production processes at concentrating plants / O.N. Tikhonov. - Moscow: Nedra, 1985. - 272 p.

4. Ulitenko, K.Y. Determination of the circulating load of grinding aggregates in the process control system / K.Y. Ulitenko, R.P. Markin // Enrichment of ores. - St. Petersburg, 2005. - №2. -

$$
\text { P. 42-44. }
$$

5. Kachan, Y.G. Model of active power generation of a drive motor of a cone crusher / Y.G. Kachan, V.I. Kornienko. - News of universities. Mining magazine. - 1987. - №3. - P. 109-113.

6. Bendat, J. Measurement and analysis of random processes / J. Bendat, A. Pirsol. - Moscow: Mir, 1974. - 650 p.

7. Piotrovsky, L.M. Electric machines / L.M. Piotrovsky. - M. - L .: Energia, 1972. $-504 \mathrm{p}$.

8. Maslov, G.S. Calculations of oscillations of shafts / G.S. Maslov. - M .: Mechanical Engineering, 1980. - 151 p.

9. Biserman, V.L. Theory of mechanical oscillations / V.L. Biserman. - Moscow: Higher School, 1980. - 408 p.

\section{Исследование технических характеристик электромеханической системы привода спирали классификатора \\ В. И. Дмитриев}

Аннотация. Рассмотрены источники вынужденных колебаний электромеханической системы спирального классификатора при действии возмущающего момента от порции песков между лопостями. Выполнен спектральный анализ сигнала мощности, потребляемой приводом спирали, и дана оценка возможности использования амплитудо-частотных характеристик колебаний для задач автоматического контроля технических и технологических параметров.

Ключевые слова: спираль классификатора, электромеханическая система, спектральное разложение сигнала, автоматический контроль. 